\title{
Developing research based learning to increase students' entrepreneurial interest
}

\author{
Zelhendri Zen ${ }^{1}$, Johari bin Sihes ${ }^{2}$, Reflianto ${ }^{3}$ \\ ${ }_{1}^{1}$ Universitas Negeri Padang, Padang - Indonesia, (zelhendrizenzen@yahoo.com) \\ ${ }^{2}$ Universiti Teknologi Malaysia, Johor Bahru - Malaysia, (p-joha@utm.my) \\ ${ }^{3}$ Universitas Negeri Malang, Malang - Indonesia, (refliantomuslim@gmail.com)
}

\begin{abstract}
The aim of research was to develop research-based learning models to increase students' entrepreneurial interest in State University of Padang. It was begun by doing the related surveys for current situation of entrepreneurial teachingdid not provide yetthe knowledge and students' entrepreneurial expectations. For that reason need a researchbased learning to empower student's strategy in the field of real business as well as to improve students' self-evaluation in enhancing their ability to take the business opportunity as the manifestation of the entrepreneurship course. This research used research and development method with Triangulation Mixed Method Design. Updating of the models was done by doing the curriculum assessment with specialists and practitioners. The collection of the data used questionnaires, interviews, documentary studies, training and mentoring as well as Focus Group Discussion (FGD). Quantitative data were analyzed by using an experimental model by using independent $t$-test. The experimental results on the three classes showed that research-based learning models can give positive impact to students' entrepreneurial interest and this model had qualified and allowable to be used as teaching materials for entrepreneurship courses at the Education Faculty of State University of Padang.The developed model was expected become a feasible choice by entrepreneurshiplecturers to the implementation of entrepreneurship course for university students at faculty of Education in State University of Padang.
\end{abstract}

Keywords: Research Based Learning, Student. Entrepreneurship

\section{Introduction}

This research is very important for higher education in improving the quality of graduates competitive in the global research era and technological advances (Shin, 2011). Therefore, the management of higher education must improve existing learning model to address the needs of the future world of research personnel. The phenomenon of the current trends in the college is how global higher education institutions race each other to improve the quality of their education, in order to become leading universities in the world, which ultimately became the target of knowledge-seekers 
to the best college in order to get the quality education and competence by building superior characteristics that are different from other college graduates (Healey, Jordan, Pell, \& Short, 2010).

Padang State University is the one of state University in West Sumatracontinue to encourage research students. To achieve these goals, as the University continues to improve itself education program to make better for the sake of such changes by applying research-based learning model in the education program. to perform quality research, basic research must be strong universities and for the reason they need to be built and focus on creating a research culture in education program as an intellectual product of the students and their lecturer.

The construction of student research quality continues to be done in order to facilitate the college mapped relationship student intellectual abilities with the implementation of the research in the field. This quality construction starts of strengthening science research methodology among faculty and students aimed to obtaining a good quality of research results and world-class quality. Discourse conduct interdisciplinary research involving many disciplines taught at the universities is ideals want to realize knowledge transformation that can be used for the advancement of national science in general and in particular to the college's progress. Through the development of research-based learning model in higher education is expected to improve the quality of higher education become the leading universities in the world. Research-based learning model is an important point initiated the integration of education into research models. In the execution would require continuous assessment models to implement the research-based learning model (Simons \& Elen, 2007).

The application of the lectures entrepreneurship model based on research is focused on the two outputs is to be achieved and to be strengthening the scientific knowledge of entrepreneurship based on research and to strengthen of technology application in the entrepreneurial course for students. In building a business started from the business plan, feasibility study, determining segment and the market target and technology applications as a sales channel will be used. These capabilities are required for university graduates, especially in facing the challenges of the Asean Economic Community (Simons \& Elen, 2007).

Feiman-Nemser (2001)stated that application of learning models based on research is the first step for a college to improve higher education management that they manage and the strengthening of graduates quality who supervised directly by skilled lecturers in conducting research based learning model in order to improve the quality of graduates and college academic achievement in the world level. If so, is there a positive correlation of the development of research-based learning in entrepreneurship courses to strengthening the quality of students being able to compete and master in the business and technology research. The purpose of this study were to 1) develop and implement a research-based instructional model to enhance the students' entrepreneurial skills, 2) Assess the effectiveness of research-based learning models to the students' entrepreneurial skill in State University of Padang.

\section{Method}

This method of this research is Research and Development (R \& D) with Triangulation Mixed Method Design(Creswell W John, 2014). The study of this development is a process to develop new products or enhance existing products that can be justified. To test the effectiveness of the product test validation of the learning model based Entrepreneurship Education research based learning are developed. Model development study is a 4-D model of development. The development model proposed by Thiagarajan, S., Semmel, D. S., \& Semmel (2010)stated that 4-D model of development consisting of four stages of development, ie define, design, develop and disseminate. Updating of the model is done through assessment curriculum specialists and practitioners in the Focus Group discussion (FGD). Collecting data had used questionnaires, interviews, documentary studies, training 
and mentoring as well as FGD. Trial data were analyzed by using an experimental model with Independent t-test test analysis.

\section{Results and Discussion}

In the define phase for the analysis of the syllabus and SAP for Entrepreneurship Subject in the fifth Semester is known that there are standard of competences to be achieved are: 1) SWOT analysis research for the next five years, 2) enable to perform feasibility analysis business, 3) enable to calculate the return on capital and cash flow predicted growth rate of the Company. The basic competencies are translated into seven indicators with the allocation of time allowed is $4 \times 40$ minutes divided into 3 sessions. For the lecture entrepreneurship by using research-based learning models was designed into more extra time for enrichment the research process in accordance with the allocation of the available time.

The results of the entrepreneurial handbook analysis used in the entrepreneurial course at fifth semester in Education Faculty, State University of Padang was compiled based on business opportunity, leadership, business management, business ethics, business feasibility, conflict management and SWOT analysis to look at the strengths, weaknesses, opportunities and challenges for the development of a business in the future, the lecture logic model that only focus on the text presented by using guide book, often causing lectures are not optimal, and the presentation of the material appears to be merely theoretical, but not applicable because there is no action in the form of field research. This condition causes the students are not creative in applying the science of entrepreneurship that can be pushed into a new entrepreneur (tenant) in the college.

Generally, the material presented in the study of used many handbook entrepreneurial lectures on theoretical studies, case studies and managerial knowledge in a business. However lacking in emphasize of applied economic studies as carrying out related research opens a new business plan, predicted profits and the company's progress in the next five years and cost analysis of promotion and profit target achievement. All these studies are real subjects which should be investigated by the prospective new entrepreneur to open a business. In the implementation of research-based learning can also be combined with the use of media film and other supporting materials in accordance with the strengthening of students to be able building a business plan based on the research of feasibility study.

Model development of research-based learning in entrepreneurship course can be done by using the film media and other media to help students learn independently in accordance with the aim of study to encourage students in critical thinking by doing the research before building a business. Lecturer applying the research-based learning mode is to support student interest with the course and become effective by using film media adapted to the material being taught. The materials studied to be close to their lives, to stay focused on the stimulation of research and direct observation by students.

At the design stage of material competence measurement, student focus to study about entrepreneurial behavior consist of 1) Describing the feasibility of a business based on research, 2) Describing the strengths, opportunities, challenges and constraints of a business based on research, and 3) Explaining how to resolve conflict management in managing venture with four assessment indicators, namely: 1) Describing the technique feasibility analysis, 2) predicting rate of the cash flow of a business 3) predicting the reciprocation of a business and 4) Coping with conflict management in maintaining the stability of the business.

On stage the development stage need the proper assessment of the prototype models that have been designed and discussed by using experts Instrument and subsequently validated by experts and entrepreneurial education curriculum consists of three experts, as the evaluator. Once validated, the 
researchers discuss directly with the validator about the validity of the prototype designed and soliciting suggestions for improvement of the prototype.

Table1. Data Validation of Learning Unit (SAP)

\begin{tabular}{|c|c|c|c|c|c|c|c|}
\hline \multirow{2}{*}{$\begin{array}{l}\text { Validation } \\
\text { Aspects }\end{array}$} & \multicolumn{3}{|c|}{ Validator } & \multirow{2}{*}{ Total } & \multirow{2}{*}{ Score } & \multirow{2}{*}{$\%$} & \multirow{2}{*}{ Inform } \\
\hline & 1 & 2 & 3 & & & & \\
\hline Aim & 8 & 8 & 8 & 24 & 24 & 100 & Valid \\
\hline Rational & 14 & 13 & 14 & $41^{\prime}$ & 42 & 97.61 & Valid \\
\hline Content Material & 16 & 14 & 14 & 44 & 48 & 91.66 & Valid \\
\hline $\begin{array}{c}\text { Fitness Model } \\
\text { With SK and KD }\end{array}$ & 15 & 16 & 14 & 45 & 48 & 93.75 & Valid \\
\hline $\begin{array}{c}\text { Suitability Model } \\
\text { With Media }\end{array}$ & 12 & 13 & 12 & 37 & 39 & 94.87 & Valid \\
\hline Total & 65 & 64 & 62 & 191 & 201 & 95.02 & Valid \\
\hline
\end{tabular}

From Table 1 can be said that the format of SAP, contents and use the model is valid, it can be seen from the total valuation of SAP with the percentage of $95.02 \%$. The curve of a product that was developed very valid if it has a percentage of $80 \%$ to $100 \%$

In the Stage of Research Based Learning model validation involves RBL model test for the fifth semester of entrepreneurship covered business topics feasibility, analysis of the strengths, opportunities, threats and weaknesses and learning conflict management efforts. Data validation results based on entrepreneurship lectures by using Research based learning Model can be viewed in the attachment 4 . In broad outline the results of the validation model can be seen in table 2 below:

Table 2. Data Validation of Research Based Learning Model

\begin{tabular}{|c|c|c|c|c|c|c|c|}
\hline \multirow{2}{*}{$\begin{array}{l}\text { Validation } \\
\text { Aspects }\end{array}$} & \multicolumn{3}{|c|}{ Validator } & \multirow{2}{*}{ Total } & \multirow{2}{*}{ Score } & \multirow{2}{*}{$\%$} & \multirow{2}{*}{ Inform } \\
\hline & 1 & 2 & 3 & & & & \\
\hline Content Models & 16 & 14 & 14 & 44 & 48 & 91.66 & Very Valid \\
\hline $\begin{array}{l}\text { Suitability Model } \\
\text { With SK and KD }\end{array}$ & 15 & 16 & 14 & 45 & 48 & 93.75 & Very Valid \\
\hline $\begin{array}{c}\text { Fitness Model } \\
\text { With Media }\end{array}$ & 12 & 13 & 12 & 37 & 39 & 94.87 & Very Valid \\
\hline Total & 43 & 43 & 40 & 130 & 135 & 96.29 & Very Valid \\
\hline
\end{tabular}

Table 2 shows that the validity of the results of the lecture model of entrepreneurship with Research-based learning approaches to every aspect ranging from $91.66 \%$ to $94.87 \%$. Overall Research-based learning model has been very valid with the percentage of $96.29 \%$ for a product developed otherwise very valid if it has a percentage of $80 \%$ to $100 \%$. In other words, materials taught by using this model are in accordance with the curriculum KKNI, and models developed to support the understanding of the business concept and the creativity of students in the learning process based entrepreneurship research.

At the practicalities prototype stage, the analysis of the practicalities of Research-based learning models of entrepreneurship course is done through testing on students FIP UNP covered Education Technology major. A teaching model has been designed by using observation sheets and 
questionnaire. Here are the responses of students on the questionnaire about the implementation of research-based learning models in entrepreneurial courses. The result analyses of questionnaire respondents are:

Table 3. Analysis of Students Response on the Research based learning models

\begin{tabular}{|c|c|c|c|c|}
\hline Statement & $\begin{array}{l}\text { Total } \\
\text { Score }\end{array}$ & $\begin{array}{l}\text { Ideal } \\
\text { score }\end{array}$ & $\%$ & Inform \\
\hline $\begin{array}{l}\text { Model Research based learning approach to encourage the } \\
\text { entrepreneurial spirit of students }\end{array}$ & 97 & 104 & 93.26 & Very Valid \\
\hline $\begin{array}{l}\text { I enjoy learning the entrepreneurship courses based on } \\
\text { research because it helps me to analyze the feasibility of a } \\
\text { business }\end{array}$ & 88 & 104 & 84.61 & Very Valid \\
\hline I can learn to master the business strategy quickly & 76 & 104 & 73.07 & Very Valid \\
\hline $\begin{array}{l}\text { I am pleased to learn entrepreneurship by using the model's } \\
\text { Research-based learning rather than just listening to the } \\
\text { explanation from the lecturer alone }\end{array}$ & 94 & 104 & 90.38 & Very Valid \\
\hline $\begin{array}{l}\text { Entrepreneurship material contents Research based learning } \\
\text { more interesting and provide reinforcement for me to run a } \\
\text { business }\end{array}$ & 89 & 104 & 85.57 & Very Valid \\
\hline $\begin{array}{l}\text { After following the learning model based learning Research } \\
\text { I am increasingly able to perform a SWOT analysis in } \\
\text { predicting the progress of a business }\end{array}$ & 90 & 104 & 86.53 & Very Valid \\
\hline I am getting trained to do research feasibility study & 93 & 104 & 89.42 & Very Valid \\
\hline $\begin{array}{l}\text { I can count Turn over business and venture capital back } \\
\text { accompanied predicted profit }\end{array}$ & 89 & 104 & 85.57 & Very Valid \\
\hline $\begin{array}{l}\text { I love research based learning model because it can } \\
\text { strengthen my business analysis and capability to } \\
\text { strengthens my research methodology }\end{array}$ & 89 & 104 & 85.57 & Very Valid \\
\hline $\begin{array}{l}\text { I can understand the process of development of an } \\
\text { enterprise up and planned surplus for the company }\end{array}$ & 93 & 104 & 89.42 & Very Valid \\
\hline 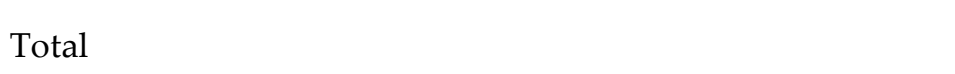 & 898 & 1040 & 86.73 & Very Valid \\
\hline
\end{tabular}

From Table 3 above shows that model is very practical, because the percentage of fifth semester student assessment in the Education Faculty of State University of Padang have ranged from $73.07 \%$ to $93.26 \%$ given the lowest ratings of students to the statement I can learn to master the business strategy rapidly $73.07 \%$. But the overall model of the Research-based learning approach has been very Valid with average percentage is $86.34 \%$.

\section{Development Results of Products Quality}

To determine the quality of the development products, validation and then practical test is required. Validation test has been done to find out the perfection of a product that has been developed. Firstly, do test normality and homogeneity data by using SPSS. Normality test showed a significance level of $0.000<0.05$, so it can be concluded that there are significant differences between the given class action with the control class. it means learning model research based learning are developed in the entrepreneurship course give better results than conventional learning models 
without integrating research on student learning. Otherwise the normal distribution of test results shows all the data obtained is normal and homogeneous.

Test analysis of respondent's responses to the questionnaire about the implementation of the research-based learning model in entrepreneurship courses. The results of the analysis are as follows:

Table 4. Analysis Results of Students' Responses the Questionnaire on Research based learning models

\begin{tabular}{lccccc}
\hline \multicolumn{1}{c}{ Statement } & $\begin{array}{l}\text { Total } \\
\text { Score }\end{array}$ & $\begin{array}{c}\text { Ideal } \\
\text { score }\end{array}$ & $\%$ & Inform \\
\hline $\begin{array}{l}\text { Model Research based learning approach to encourage the } \\
\text { entrepreneurial spirit of students }\end{array}$ & 97 & 104 & 93.26 & Very Valid \\
\hline $\begin{array}{l}\text { I enjoy learning the entrepreneurship courses based on } \\
\text { research because it helps me to analyze the feasibility of a } \\
\text { business }\end{array}$ & 88 & 104 & 84.61 & Very Valid \\
\hline $\begin{array}{l}\text { I can learn to master the business strategy quickly } \\
\text { I am pleased to learn entrepreneurship by using the model's }\end{array}$ & 76 & 104 & 73.07 & Very Valid \\
\hline $\begin{array}{l}\text { Research-based learning rather than just listening to the } \\
\text { explanation from the lecturer alone }\end{array}$ & 94 & 104 & 90.38 & Very Valid \\
\hline $\begin{array}{l}\text { Entrepreneurship material contents Research based learning } \\
\text { more interesting and provide reinforcement for me to run a } \\
\text { business }\end{array}$ & 89 & 104 & 85.57 & Very Valid \\
\hline $\begin{array}{l}\text { After following the learning model based learning Research } \\
\text { I am increasingly able to perform a SWOT analysis in } \\
\text { predicting the progress of a business }\end{array}$ & 90 & 104 & 86.53 & Very Valid \\
\hline $\begin{array}{l}\text { I am getting trained to do research feasibility study } \\
\text { I can count Turn over business and venture capital back } \\
\text { accompanied predicted profit }\end{array}$ & 93 & 104 & 89.42 & Very Valid \\
\hline $\begin{array}{l}\text { I love research based learning model because it can } \\
\text { strengthen my business analysis and capability to } \\
\text { strengthens my research methodology }\end{array}$ & 89 & 104 & 85.57 & Very Valid \\
\hline $\begin{array}{l}\text { I can understand the process of development of an } \\
\text { enterprise up and planned surplus for the company }\end{array}$ & 93 & 104 & 89.42 & Very Valid \\
\hline \begin{tabular}{l} 
Total \\
\hline
\end{tabular} & 898 & I040 & 86.34 & Very Valid \\
\hline
\end{tabular}

From Table 4 above shows that the practical model of Research based learning is very practical, because the percentage of fifth semester student ranged from $73.07 \%$ to $93.26 \%$ given the lowest ratings of students to the statement I can learn to master the business strategy of rapidly $73.07 \%$. But the overall model of the Research-based learning approach has been very Valid with average percentage is $86.34 \%$.

Hypothesis testing whether there are differences in the effectiveness of conventional learning models with a research-based learning model in entrepreneurship courses. The findings and statistical analysis can be explained as follows: 
Table 5 Test Comparison with Conventional Model RBL in Student TP Group 1

\begin{tabular}{|c|c|c|c|c|c|c|c|c|c|}
\hline & \multicolumn{2}{|c|}{$\begin{array}{l}\text { Levene's Test for } \\
\text { quality of variance }\end{array}$} & \multicolumn{7}{|c|}{ t-test for equality of Means } \\
\hline & $\mathrm{F}$ & Sig. & $\mathrm{t}$ & $\mathrm{df}$ & & Q (2-tailed) & $\begin{array}{l}\text { Std.error } \\
\text { difference }\end{array}$ & $\begin{array}{r}5 \% \mathrm{col} \\
\text { interv } \\
\text { diff } \\
\end{array}$ & $\begin{array}{l}\text { idence } \\
l \text { of the } \\
\text { ence }\end{array}$ \\
\hline & & & & & & & & Lower & upper \\
\hline $\begin{array}{r}\text { Equal variance } \\
\text { assumed }\end{array}$ & 10.060 & .003 & -8.57( & 40 & .000 & 15.071 & 1.759 & 8.626 & 11.517 \\
\hline $\begin{array}{r}\text { Equal variance not } \\
\text { assumed }\end{array}$ & & & -8.57( & 29.005 & .000 & 15.071 & 1.759 & 8.668 & 11.475 \\
\hline
\end{tabular}

From Table 5 above are found no significant difference between the given class action with the control class. It means that research based learnign model are developed in the entepreneurship course give better results than conventional learning models to Educational Technology Student in the Group one.

In the test study of research based learning model both were granted to students in the Group 2 was also obtained significant difference between the given class action Research Based Learning with the control class, which models Research Based Learning, can improve students' motivation and learning outcomes to study the entrepreneurship courses.

Table 6 Test Comparison between Conventional Model and RBL for Models School in Student TP Group 2

\begin{tabular}{cccccccccc}
\hline & \multicolumn{7}{c}{$\begin{array}{c}\text { Levene's Test for } \\
\text { quality of variance }\end{array}$} \\
& $\mathrm{F}$ & Sig. & $\mathrm{t}$ & $\mathrm{df}$ & & $\mathrm{t}$-test for equality of Means \\
\hline & & & & & & & Lower & upper \\
\hline $\begin{array}{c}\text { Equal variance } \\
\text { assumed }\end{array}$ & .476 & .494 & -6.101 & 40 & .000 & -12.095 & 1.982 & -16.102 & -8.089 \\
\hline $\begin{array}{c}\text { Equal variance not } \\
\text { assumed }\end{array}$ & & & -6.101 & 39.251 & .000 & -12.095 & 1.982 & -16.104 & -8.086 \\
\hline
\end{tabular}

From Table 6 above found no significant difference between the given class action Rsearch Based Learning is learning to control class (conventional learning) received student Learning Technology Group 2 at the State University Faculty of Education.

In the test study of Research based learning model of research-based learning when given to students of Educational Administration of Education Faculty of UNP also found significant differences between the given class action with Research Based Learning and conventional classroom, where models of Research Based Learning can improve students' motivation and learning outcomes to the entrepreneurship courses into the life?

Table 7 Comparison Test between Conventional Model and RBL in group 3

\begin{tabular}{cccccccccc}
\hline & \multicolumn{7}{c}{$\begin{array}{c}\text { Levene's Test for } \\
\text { quality of variance }\end{array}$} & t-test for equality of Means \\
& F & Sig. & t & df & & Q (2-tailed) & $\begin{array}{c}\text { Std.error } \\
\text { difference }\end{array}$ & $\begin{array}{c}5 \% \text { confidence } \\
\text { interval of the } \\
\text { difference }\end{array}$ \\
\hline & & & & & & & Lower & upper \\
\hline $\begin{array}{c}\text { Equal variance } \\
\text { assumed }\end{array}$ & 1.524 & .224 & -5.633 & 40 & .000 & -10.405 & 1.847 & 14.138 & -6.672 \\
\hline $\begin{array}{c}\text { Equal variance not } \\
\text { assumed }\end{array}$ & & & -5.633 & 37.826 & .000 & -10.405 & 1.847 & 14.145 & -6.665 \\
\hline
\end{tabular}


From table 7 above are found no significant difference between the given class action of Research Based Learning and conventional learning. Based on the results of t-test hypotheses by using post test results showed that the three classes of students test well on Education Technology Group 1, Group 2 and Students Education Administration in group 3 shows that research-based learning model for entrepreneurship courses in education faculty of Padang State University can improve entrepreneurial students' motivation and learning outcomes.

From these results it can be concluded that this research has resulted the practical research based learning model for the entrepreneurship courses that can improve students' motivation and learning outcomes in Education Faculty of Padang State University. Research based learning model for entrepreneurship courses at the practical level validity $92.35 \% 83.1 \%$

The development of research-based learning model is proven to boost students' interest in the entrepreneurship work at education faculty of the state university. The development of researchbased learning model is done as an effort to improve the quality of graduates to skilled and creative in finding science and also to develop their own potential. The development of self potency to life skills-oriented are expected to be able to compete for looking jobs after graduating from the college, and even ready to open their own jobs. Through entrepreneurial learning by using research-based learning method to student of education faculties in State University of Padang aims to train students to learn while researching. By researching, students acquire knowledge in the field. Implementation in the life of entrepreneurship, students will be trained to take a good business decision based on consideration of the research results first in order to build the business targets can be developed.

The application of entrepreneurial research-based learning has also been performed at leading universities in the United States and Europe. The ultimate goal is that students are not only strong in terms of cognitive, but also strong in terms of creative and innovative so being able to produce economic value for society and themselves as college graduates. In addition to cultivate research based learning in the campus in order to effort the realization of vision and missions of the university that wants to become a leading university in terms of education and research, well-known the University-Based Research.

The results of this study are consistent with the research was conducted at the University of Americas and Europe, as reported by (Angela Brew, 2001)in his research that a lot of the learning program is now in the college implement the research based learning, where the team of academic (lecturer) involve their students directly come into the research, Other research Brew \& Jewell (2012) stated that almost all universities in the United states and Europe implement research-based learning model. Practices of research based learning is then developed with the aim to increase the research capability of graduates and entrepreneurial skills of graduates so that when they graduate from the university where they studied, they are not difficult to find jobs and even they can create employment for themselves and employment for others. This is a creative and innovative advantage that can be gained from the implementation of research-based learning model in higher education (Kuh, 2008).

The results of this study indicate that the development of research-based learning model in entrepreneurship courses at the Faculty of Education in State University of Padang proven to improve students' research and students' desire for entrepreneurship. It can be seen from the appearance of several students then develop their culinary business and digital media in the line of creative industries in the campus under the guidance of faculty. This success is the first step that can be measured from the positive impact of the application of the research based learning model on the entrepreneurship courses. In terms of the effectiveness of the model, research-based learning contribute about $92.53 \%$ of the students prefer the research because by using this model students become more happy and creative. While practicality, implementation of this model accounted for $83.1 \%$ make students enjoy participating to follow the entrepreneurial class in the research-based learning model. These results proven that the application of research-based learning model in the course of entrepreneurial class in the Education Faculty of State University of Padang, being more 
effective, in addition to familiarize faculty and students examine together also strengthen their research quality at the college level.

According to A. Brew (2010), Beckman \& Hensel, (2009)the implementation of research based learning on campus provides many advantages such as this model contributes to improving the quality of graduates, individual research quality and quality of collaborative research at the university level. Besides the application of research-based learning model in the entrepreneurial class much bigger contribution to bear out many talented students in the field of creative economy industry. With this model, according A. Brew (2010), familiarize students creative thinking and responsive in making decisions based on the results of research that has been done prior to opening or expanding a business.

Results of this study can encourage universities, particularly faculty, staff and students from educational faculty to build a study center of the research that can contribute to the strengthening of institutions to realize the vision and mission of the related University become Research University. According to Smith \& Rust (2011), the implementation of research-based learning model is the bridge leading Research University where in all teaching and learning activities on campus will always bear important research that contributes new knowledge for education, not only in Indonesia, but also at the international level. According to Dekker \& Wolff (2016)Teaching and research-based learning is an effort to improve the quality of education that proved able to bring a lot of research that provides new knowledge so that the development of creativity and innovation of various research studies in the future. The impact of this learning model ultimately contributes to the strengthening of the 'pedagogy system in the higher education.

The activities of research based learning as we did in the entrepreneurship courses involving students of educational faculty at state university of Padang has encouraged the managerial policy in the improvement of research at the academic level, and improve the system of pedagogy at the college level in State University of Padang are increasingly the excellence and innovation in each of their research graduate. In this way the graduates of State University of Padang was expected to be more capable and ready to compete with other university graduates in the world. At the same time, the model of research based learning in entrepreneurship courses are not only strengthening research at the academic level, as well as opening opportunities for creative students at the campus level by building various businesses in the creative industries sector as culinary industry and digital printing media successfully during study in the campus. This study is consistent with the argument of (Lambert, 2009)stating the need to build an academic research center in the higher education in order to improve the academic quality, curriculum and research-based learning in building the practical pedagogy system which encourage the academic community to think critically to constantly innovate to advance their educational institution.

Other studies are also consistent with this study such as the research done in the United States and the United Kingdom by Blackmore, P., \& Cousin(2003); (Angela Brew \& Jewell (2012);Levy \& Petrulis (2012) and then the academic research from faculty and students isn a collaborative study by Seymour, Hunter, Laursen, \& Deantoni, (2004) commented that the research based learning is very effective to build willingness academic research, although it requires a long time, but at least this model contributes any much advantages, ie improving the quaslity of learning and academic research abilities of students and faculty at the college level. In addition, this model is also useful to reduce the sense of boredom than conventional learning models over the years.

Blackmore, P., \& Cousin(2003) reported that the students were very appreciative with research based learning, because by this way they get a chance to be a scientist and also a researcher at the academic level. At the University of Warwick, a research study centers was built for their students meeting, discussing and researching related to the development of knowledge they have learned. The existence of this research study center directly encourage the participation of students are more actively engaged in the discussion of scientific and research activities at the college level. In this way the University of Warwick able to cultivate research behavior in any student learning on campus. 
However, some students sometimes difficult to divide their roles when he returned to the classroom as a student after collaboration with their professors in the research (Blackmore, P., \& Cousin, 2003; Seymour, Hunter, Laursen, \& Deantoni, 2004)

Research based learning that we conducted on students of educational faculty at State University of Padang in the entrepreneurial class was more emphasis on the training in the line of creative economy industry and market research to look for business opportunities that can be developed in the creative industries sector, in this case focusing on creative industries of culinary and digital printing media. From our findings, research-based learning model showed a good result to strengthening students' entrepreneurial skills in the sector of creative industries, as well as the strengthening of creativity and innovation of students in developing their knowledge and thus provide economic value to their lives, and strengthening the research at the student level. This point is important for strengthening the students' final assignment when their thesis. Research findings indicate that the research-based learning has the potential to put students at the heart of the university, as the manufacturer is no longer as consumers. In turn, this requires a leader who is able to share their experience to the students involved in the research-based learning with a good pedagogical system at the college level.

\section{Conclusions}

Based on the results and discussion of the research that has been done it can be concluded that this research has produced instructional books of research-based entrepreneurship courses. Instructional model of research based learning for entrepreneurship courses that have been generated are very valid with a percentage of $92.35 \%$. While the practicalities test results through questionnaires is categorized very practical with a percentage of $83.1 \%$.

\section{Acknowledgments}

This study was supported by State University of Padang. We thanks so much to our colleagues of Dr. Alwen Bentri, M.Pd who provided insight and expertise that greatly contribution to the research analysis. We also thanks a lot to Reflianto, M.Pdwho help us in the particular technique, methodology and comments for greatly improvement of this paper.

\section{References}

Beckman, M., \& Hensel, N. (2009). Making Explicit the Implicit: Defining Undergraduate Research. CUR Quarterly, 29(4), 40-44.

Blackmore, P., \& Cousin, G. (2003). Linking teaching and research through research-based learning. Educational Developments, 4, 24-27.

Brew, A. (2001). Conceptions of Research: A phenomenographic study. Studies in Higher Education, 26(3), 271-285. https://doi.org/10.1080/03075070120076255

Brew, A. (2010). From the International Desk. An Australian Perspective on Undergraduate Research. Quarterly, 37-42.

Brew, A., \& Jewell, E. (2012). Enhancing quality learning through experiences of research-based learning: Implications for academic development. International Journal for Academic Development, 17(1), 47-58. https://doi.org/10.1080/1360144X.2011.586461

Creswell W John. (2014). Research Design, Qualitative, Quantitative and Mixed Methods Approaches (4th ed.). SAGE Publication, Inc.

Dekker, H., \& Wolff, S. W. (2016). Re-inventing Research-Based Teaching and Learning Paper prepared for presentation at the meeting of the European Forum for Enhanced Collaboration in 
Teaching of the European University Association in Brussels on 5 December 2016, (December). Feiman-Nemser, S. (2001). From preparation to practice: Designing a continuum to strengthen and sustain teaching. Teachers College Record, 103(6), 1013-1055. https://doi.org/10.1111/01614681.00141

Healey, M., Jordan, F., Pell, B., \& Short, C. (2010). The research-teaching nexus: A case study of students' awareness, experiences and perceptions of research. Innovations in Education and Teaching International, 47(2), 235-246. https://doi.org/10.1080/14703291003718968

Kuh, G. D. (2008). High-impact educational practices: What they are, who has access to them, and why they matter. Washington, DC: Association of American Colleges and Universities.

Lambert, C. (2009). Pedagogies of participation in higher education: A case for researchbased learning. Pedagogy, Culture and Society, 17(3), 295-309. https://doi.org/10.1080/14681360903194327

Levy, P., \& Petrulis, R. (2012). How do first-year university students experience inquiry and research, and what are the implications for the practice of inquiry-based learning? Studies in Higher Education, 37(1), 85-101. https://doi.org/10.1080/03075079.2010.499166

Seymour, E., Hunter, A. B., Laursen, S. L., \& Deantoni, T. (2004). Establishing the benefits of research experiences for undergraduates in the sciences: First findings from a three-year study. Science Education, 88(4), 493-534. https://doi.org/10.1002/sce.10131

Shin, J. C. (2011). Teaching and research nexuses across faculty career stage, ability and affiliated discipline in a South Korean research university. Studies in Higher Education, 36(4), 485-503. https://doi.org/10.1080/03075071003759052

Simons, M., \& Elen, J. (2007). The "research-teaching nexus" and "education through research": An exploration of ambivalences. Studies in Higher Education, 32(5), 617-631. https://doi.org/10.1080/03075070701573781

Smith, P., \& Rust, C. (2011). The potential of research-based learning for the creation of truly inclusive academic communities of practice. Innovations in Education and Teaching International, 48(2), 115125. https://doi.org/10.1080/14703297.2011.564005

Thiagarajan, S., Semmel, D. S., \& Semmel, M. I. (2010). Instructional Development for Training Teachers of Exceptional Children: A Sourcebook. Center for Innovation in Teaching the Handicapped. Indiana: Indiana University Bloomington. 